\section{Giorgio Zanchin}

\section{Sources}

\section{On pathophysiology}

Samuel Tissot (1728-1797): A hypothesis on the peripheral origin of migraine.

“[...] on ne peut plus douter que la plus grande partie des migraines ne soient la suite d'une cause irritante dans l'estomac, qui agit sur les rameaux des nerfs, qui se distribuent à la partie antérieure et latérale de la tête."

Oeuvres de Monsieur Tissot. Nouvelle édition (1784). Tome troizième, contenant le traité de la catalepsie, de l'extase, de l'anoesthesie, de la migraine, et des maladies du cerveau. François Grasset \& comp., Lausanne, p $120^{1}$.

[...] it can no longer be doubted that most migraines are the consequence of an irritating cause within the stomach that acts on the nerve branches, which are distributed at the frontal and lateral region of the head ${ }^{2}$.

\section{G. Zanchin ( $($ )}

Department of Neurosciences,

Section of History of Medicine,

Headache Centre, University of Padua,

Via Falloppia 50, I-35121 Padua, Italy

e-mail: giorgio.zanchin@unipd.it

Tel.: +39-49-8272335/6

Fax: $+39-49-8272335$
Sir Edward Liveing (1832-1919): The "Nerve-storm" theory about migraine originating into the brain.

"There is, however, another point of view, differing widely from any of the preceding, from which megrim and other paroxysmal nervous affections of the same class may be regarded, and to which I wish now to direct attention: it is that which considers them in the light of Nerve-storms ... On this theory, then, the fundamental cause ... is to be found, not in any irritation of the visceral or cutaneous periphery, nor in any disorders or irregularity of circulation, but in a primary and often hereditary vice of morbid disposition of the nervous system itself; this consists in a tendency on the part of the nervous system centres to the irregular accumulation and discharge of nerve-force ... The immediate antecedent of an attack is a condition of unstable equilibrium and gradually accumulating tension in the parts of the nervous system more immediately concerned, while the paroxysm itself may be linked to a storm, by which this condition is dispersed and equilibrium for the time restored..."

Liveing E (1873) On Megrim, sick-headache and some allied disorders. Churchill, London, p $335^{1}$.

\section{On the classification}

Aretaeus the Cappadocian (II century A.D.): The first, although very concise, headache classification. Roughly, we could identify episodic tension-type headache with Cephalalgia; chronic and possibly secondary headache with Cephalea; and migraine with Eterocrania.

"Si caput repente obvia quaque de causa, per plures etiam dies dolorem patitur; hic affectus Cephalalgia 
graece nominatur; si multo tempore dolor infestare assuevit, et per longos, frequentesque circuitus, ac in dies major violentiorque insultat difficulter sanationem admittens; id genus Cephaleam graeco vocabulo appellamus... Praeterea dolor modo est in toto capite, modo in dextra magis, modo in sinistra, modo circa frontem...haecque eodem die incerte... Id vitium solum Eterocrania dicitur...nausea, et vomitus biliosus comitantur...pigritia multa adest, et capitis gravitas; fugiunt enim quodam modo lucem, tenebraeque his aegritudinem sustinent."

De causis, et notis diuturnorum affectuum liber primus. In: Junio Paulo Crasso. Aretaei Cappadocis medici insignis ac vetustissimi libri septem (1763). Tipografia Remondiniana, Venetiis, pp 48-49. The original Greek text can be found in: Aretaeiou Cappadociou Peri aition semeion oxeon kai chronion pathon. Peri therapeias oxeon kai chronion pathon (1735). Editionem curavit Hermannus Boerhaave. Apud Janssonios Vander, Lugduni Batavorum ${ }^{1}$.

If an individual has a sudden headache attack following an unimportant cause of brief duration, this affection is called with the Greek terminology Cephalalgia, even if the crisis is prolonged for more days. But, if the disturbance is of lasting duration, for long, often recurrent periods, and if, in time, the head pain becomes more intense and unbearable showing resistance to treatment, then the Greek term is Cephalea... When pain affects sometimes the entire head, other times it localises on the right, other times on the left or on the forehead... and at times the attacks change site during the same day... The specific name of this affection is Eterocrania...it is accompanied with nausea and vomiting of biliary material...there is a great deal of listlessness, heaviness of the head: [the patients] escape the light, darkness alleviates their suffering ${ }^{2}$.

\section{On the migraine aura}

Charles Le Pois (Carolus Piso, 1563-1636): Probably the first detailed description of migraine aura, although without visual disturbance.

“[...] primum quidem aegra vertiginem praesentire, tum non ita post minimi sinistrae manus digiti torpidum quendam sensum ac motum veluti quarumdam vagantium formicarum (qui eodem fere instant universum per brachium aurae cujusdam instar ascendentis efferretur) ac mox annularis, mediique, \& sequentium ordine \& successive stuporem pariter, qui simitu integrum brachium comprehenderet..."

Selectiorum observationum et consiliorum de praetervisis hactenus morbis affectibusque praeter naturam, ab aqua seu serosa colluvie et diluvie ortis, liber singularis (1733). Apud Gerardum Potuliet, Lugduni Batavorum, p 75․ This observation was firstly published in 1618 .

[...] the patient first felt dizzy and a little while later numbness in the little finger of the left hand, like a sensation and movement of wandering ants (which started from the same finger and spread to the whole arm and advanced in the same way of a shiver), and immediately afterwards it spread to the ring finger, to the middle finger and to the other fingers in succession, and likewise, then a sort of hindrance presented itself in the whole $\operatorname{arm}^{2}$.

\section{On osmophobia and other provoking external stimuli}

Bernardino Ramazzini (1633-1714): The provoking action, not only of foul smells, but also of pleasant smells, on headache; plus preventative suggestions.

"De pharmacopoeorum morbis.

Nonnullos audivi verno tempore, quando rosarum infusiones faciunt, pro syrupis aureis, et cum tota officina pestana rosaria redolet, de gravi capitis dolore conquerentes, aliis alvum laxari.

Quibus ergo odora canum vis inest, hujusmodi odores, quantum possunt, effugiant, accidentidem ab officina exeant ad auram captandam, seu odorata quaedam sibi magis familiaria, quibus recreari soleant, et sibi infestos obtundant, naribus persaepe apponant."

Opera Omnia (1742) Vol II. Apud Paulum et Isaacum Vaillant, Londini, p 22 ${ }^{1}$. This observation was firstly published in 1700 .

On the diseases of pharmacists.

In spring when they prepare infusions of roses for golden syrups, and when the whole shop smells of rose beds of Paestum, I have heard some complain of severe headache, others of diarrhea.

Those in whom the power of scent of dogs resides should run away from such smells as far as possible, and again and again go out of the shop to breathe fresh air, or very often hold more welcome scents to their noses, by which they may regularly obtain relief, and blunt the offending smells ${ }^{3}$.

"Interdum etiam non solum a graveolentibus graviter affici quosdam Pharmacopoeos accepi... quod nonnullis nauseam ac vomitum ciet, verum etiam a suaveolentibus..."

Opera Omnia (1742) Vol II. Apud Paulum et Isaacum Vaillant, Londini, p 22 $2^{1}$. This observation was firstly published in 1700 . 
I have observed that, at times, with some pharmacists, not only do bad odours have a harmful effect, provoking nausea and vomiting, but pleasant odours also ${ }^{2}$.

\section{Sir Edward Liveing (1832-1919): Other provoking conditions.}

"I refer to various circumstances which produce a powerful impression on, or require a prolonged exercise of, the organs of sense; such as lights, loud noises, strong odours, foul air, and the like; and particularly the various combinations of these to which different classes of people are exposed in factories, workrooms, public assemblies, and in the various forms of what is called sight-seeing."

Liveing E (1873) On Megrim, sick-headache and some allied disorders. Churchill, London, p $53^{1}$.

\section{Samuel Tissot (1728-1797): A further addition to the list on the subject.}

"Généralement la migraine attaque dans toutes les saisons, dans tous les temps, à toutes les heures; elle est assez indépendante de beaucoup de circonstances accidentelles, qui déterminent les accès de simples maux de tête; et quand les migraines sont bien réglées, rien n'incommode dans l'entre-deux. Mais chez les personnes qui ont les nerfs délicats, la migraine est quelquefois occasionnée, comme les simples maux de tête, par la chaleur des apartemens, par le froid des pieds, par le vin, par les odeurs, par quelques alimens, et surtout par les acides”.

Oeuvres de Monsieur Tissot (1784) Nouvelle édition. Tome treizième, contenant le traite de la catalepsie, de l'extase, de l'anoesthesie, de la migraine, et des maladies du cerveau. François Grasset \& comp., Lausanne, p $107^{1}$.

Migraine generally affects people in all seasons, circumstances and at any time; it is rather independent from most of the accidental circumstances that determine spells of mere headache, and when migraines occur at a regular interval in the intercritical period they are not a bother. But, in people who have delicate nerves, migraine is sometimes caused, as with a simple headache, by hot environments, cold feet, wine, odours, some foods, and above all by acids ${ }^{2}$.

\section{On cluster headache}

Thomas Willis (1621-1675): One of the earliest possible references, even if incomplete, suggestive of this form of primary headache.

"Usitatum est, cephalalgiae [...] circa aequinoctia, aut solstitia accessiones recrudescere [...] sed plerumque [cephalalgiae] periodos subordinatas nactae, nycthemeri cijusque spatio statis quibusdam horis infestare solent”.

De anima brutorum exercitationes duas. In: Opera omnia tomus secundus (1694). Gasparis Storti, Coloniae, p 357. First published in $1672^{1}$.

It is common for the attacks to increase around equinoxes and solstices, often in "subordinate periods", they usually infest at certain fixed hours within the space of every day and night ${ }^{4}$.

\section{On therapy}

Quintus Serenus Sammonicus (II century A.D.): An example of popular medicine in Rome during the Imperial Period. Magic-ritual elements are evidently present, such as the number three and the introduction of the healing preparation on the opposite site of pain location.

"Portio si capitis morbo temptatur acuto, allia diversam lana contecta per aurem inducta prosunt, et eodem balsama pacto; allia vel ternis piperis terna addita granis trita linis: certam dabit haec tibi cura salutem."

A. Cornel Celsus et Q. Serenus Samonicus De Medicina (1750). Josephus Cominus, Patavii, p $340^{1}$.

During acute pain that affects part of the head, garlic wrapped in wool, and in the same way, the balms introduced in the ear on the opposite side, or massage with three garlic cloves and three grains of pepper minced together: this treatment will surely contribute to recovery ${ }^{2}$.

Alexander Trallianus (525-605 A.D.): A therapeutical prescription in accordance with the humoral view.

"Si biliosus humor dolorem peperit, sumant aegri ante omnia panem ex aqua tepida, ut quae supra modum ipsis auxilietur. Caeterum etiam malva, et lactuca comestae prosunt in universum, cibus sit humectans et balnea temperata, postremo purgatio, quae ex Picra et Scamonia, et aliis qua bilem citra magnum dolorem purgare solent, adhiberi debet."

Alexandri Tralliani medici libri duodecim de re medica (1552). Venetiis, apud Hieronymum Scotum, p 13 ${ }^{1}$. The original Greek text can be found in: Alexandri Tralliani medici libri XII (1548). Lutetiae: ex officina Rob. Stephani, typographi regii, typis regiis.

If the biliary humour has caused pain, the patients should eat, in the first place, bread soaked in warm water, a measure that will be of great help. Moreover, eating mallow and lettuce is always healthy; the food should be moist and one 
should bathe in warm water; lastly, use a laxative derived from Picra ${ }^{5}$ and Scammony ${ }^{6}$, and others [vegetables], which usually purify the bile without too much pain ${ }^{2}$.

\section{Notes}

${ }^{1}$ Courtesy of the "Pinali Antica" Library, Padua University Medical School.
${ }^{2}$ Author's translation.

${ }^{3}$ Quoted from: Zanchin G, Rossi P, Isler H, Maggioni F (1996) Headache as an occupational illness in the treatise "De morbis artificum diatriba" of Bernardino Ramazzini. Cephalalgia 16(2):79-86. ${ }^{4}$ Quoted from: Isler H (1986) Thomas Willis' two chapters on headache of 1672: a first attempt to apply the "new science" to this topic. Headache 26(2):95-98.

${ }^{5} \mathrm{~A}$ bitter salad.

${ }^{6}$ Convolvulus scammonia, from which the dried root was used, containing resinous glycosides with a purgative effect. 